\title{
Skrining fitokimia dan aktivitas antibakteri ekstrak etanol daun sirsak (Annona muricata L.) pada Streptococcus mutans ATCC 35668
}

\author{
Friska Ani Rahman*, Tetiana Haniastuti**, Trianna Wahyu Utami*** \\ *Program Studi Higiene Gigi, Fakultas Kedokteran Gigi, Universitas Gadjah Mada, Yogyakarta, Indonesia \\ ${ }^{* *}$ Departemen Biologi Mulut, Fakultas Kedokteran Gigi, Universitas Gadjah Mada, Yogyakarta, Indonesia \\ ${ }^{* * *}$ Departemen Biomedika, Fakultas Kedokteran Gigi, Universitas Gadjah Mada, Yogyakarta, Indonesia \\ *JI Denta No 1, Sekip Utara, Yogyakarta, Indonesia; e-mail: friska_ani@ugm.ac.id
}

Submisi: 23 Juni 2016; Penerimaan: 4 Oktober 2016; Publikasi online: 28 April 2017

\begin{abstract}
ABSTRAK
Karies gigi merupakan salah satu penyakit gigi yang banyak terjadi di Indonesia. Salah satu bakteri yang berperan penting dalam terjadinya karies gigi adalah Streptococcus mutans. Tanaman sirsak (Annona muricata L.) telah digunakan secara turun temurun oleh sebagian masyarakat Indonesia untuk mengobati penyakit. Perbedaan kondisi lingkungan tempat tumbuh suatu tanaman dapat menyebabkan perbedaan jenis dan jumlah dari metabolit sekunder yang terkandung dalam tanaman. Penelitian ini bertujuan untuk mengetahui aktivitas antibakteri ekstrak etanol daun sirsak terhadap S.mutans ATCC 35668 serta menentukan kandungan senyawa metabolit sekunder. Jenis penelitian merupakan ekperimental laboratoris, dilakukan ekstraksi pada daun sirsak dengan metode maserasi menggunakan pelarut etanol $70 \%$. Ekstrak etanol daun sirsak selanjutnya dilakukan skrining fitokimia dengan uji kromatografi lapis tipis (KLT). Uji aktivitas antibakteri dilakukan dengan metode dilusi cair. Penelitian ini menggunakan 5 konsentrasi yaitu 150; 125; 100; 75; 50 mg/ml. DMSO $5 \%$ digunakan sebagai kontrol negatif dan Chlorheksidine 5\% digunakan sebagai kontrol positif. Berdasarkan uji KLT, ekstrak etanol daun sirsak mengandung senyawa metabolit sekunder berupa saponin, terpenoid, steroid, flavonoid, tanin, alkaloid. Ekstrak etanol daun sirsak dapat menghambat pertumbuhan bakteri S.mutans ATCC 35668 dengan KHM $125 \mathrm{mg} / \mathrm{ml}$. Data dianalisis dengan menggunakan uji parametrik Anava satu jalur. Konsentrasi ekstrak terhadap pertumbuhan koloni S.mutans ATCC 35668 menunjukkan hasil signifikan $(p<0,05)$. Ekstrak etanol daun sirsak memiliki aktivitas antibakteri terhadap S.mutans ATCC 35668 dengan KHM pada konsentrasi $125 \mathrm{mg} / \mathrm{ml}$. Ekstrak etanol daun sirsak mengandung senyawa metabolit sekunder berupa saponin, terpenoid, steroid, flavonoid, tanin dan alkaloid.
\end{abstract}

Kata kunci: antibakteri; ekstrak etanol daun sirsak (Annona muricata L.); fitokimia; Streptococcus mutans ATCC 35668

\begin{abstract}
Phytochemical screening and antimicrobial activities of ethanolic extracts Annona muricata $L$. on Streptococcus mutans ATCC 35668. Dental caries is one of dental diseases frequently occurred in Indonesia. Streptococcus mutans plays an important role in the pathogenesis of dental caries. Soursop plant (Annona muricata $L$ ) has been used by some communities in Indonesia to cure various kinds of disease. Different environment where the plants grow may lead to the differences in the type and amount of secondary metabolites. The aim of this study was to evaluate the effect of the ethanol extract of Annona muricata L. leaves on the growth of S. mutans ATCC 35668 and phytochemicals analysis of Annona muricata $L$. leaves ethanol extract. The type of the research is an experimental laboratory, Soursop leaves were extracted by maceration using ethanol $70 \%$. The extract obtained was then carried out phytochemical screening with thin layer chromatography (TLC). Concentrations of extract tested were: 150; 125; 100; 75; $50 \mathrm{mg} / \mathrm{ml}$. Chlorhexidine $5 \%$ was used as a positive control while DMSO 5\% was used a negative control. Based on phytochemical screening, Annona muricata L. leaves ethanol extract contained secondary metabolite compounds, such as saponin, terpenoid, steroids, flavonoids, tannins and alkaloids. MIC obtained at concentration of $125 \mathrm{mg} / \mathrm{ml}$. Data were analyzed by using one-way Anava parametric test. The effect of extract concentration on the growth of colonies of S. mutans ATCC 35668 showed a significant result $(p<0.05)$ among groups tested. Annona muricata L. leaves ethanol extract had antibacterial activity against S. mutans ATCC 3566 at MIC concentration of $125 \mathrm{mg} / \mathrm{ml}$. and contained secondary metabolite compounds, such as saponins, terpenoids, steroids, flavonoids, tannins and alkaloids.
\end{abstract}

Keywords: antibacterial; Annona muricata L. leaves ethanol extract; phytochemicals; Streptococcus mutans ATCC 35668

\section{PENDAHULUAN}

Karies gigi merupakan salah satu penyakit gigi yang banyak terjadi di Indonesia. Proses karies melibatkan banyak faktor, yaitu: pejamu (gigi dan saliva), substrat (makanan), bakteri penyebab karies dan waktu. ${ }^{1}$ Bakteri yang melekat pada permukaan gigi dengan faktor-faktor lainnya dapat menimbulkan karies. ${ }^{2}$ Salah satu bakteri yang 
berperan penting dalam terjadinya karies gigi adalah Streptococcus mutans. ${ }^{3}$ Streptococcus mutans merupakan bakteri yang bersifat kariogenik karena mampu untuk menempel pada permukaan gigi. Perubahan ekologi ditandai dengan peningkatan proporsi S. mutans dan spesies lain yang bersifat asidurik dan asidogenik. ${ }^{4}$

Upaya pencegahan sangat diperlukan untuk dapat mengontrol faktor resiko karies. ${ }^{5}$ Salah satu upaya pencegahan karies dapat dilakukan dengan penggunaan bahan antibakteri. ${ }^{6}$ Penggunaan antibakteri komersil ternyata mempunyai beberapa efek samping seperti perubahan flora normal dan resistensi mikroorganisme di dalam rongga mulut. ${ }^{7}$ Fakta inilah yang mendorong pencarian bahan antibakteri alternatif dari bahan alami yang dapat melindungi gigi dari proses karies. ${ }^{8}$

Tanaman sirsak (Annona muricata L.) merupakan salah satu tanaman yang banyak digunakan di Indonesia dalam pengobatan tradisional. ${ }^{9}$ Daun sirsak secara tradisional juga digunakan untuk mengobati sakit kepala, demam, sakit gigi, batuk dan asma. ${ }^{10}$ Daun sirsak menunjukkan adanya kandungan senyawa aktif alkaloid, tanin, flavonoid. ${ }^{11}$ Tanaman yang mengandung flavonoid dan alkaloid menunjukkan kemampuan menghambat pertumbuhan bakteri kariogenik, ${ }^{12}$ selain itu tanin juga mampu menghambat pertumbuhan bakteri. ${ }^{13}$ Perbedaan kondisi lingkungan tempat tumbuh suatu tanaman dapat menyebabkan perbedaan jenis dan jumlah dari metabolit sekunder yang terkandung dalam tanaman, ${ }^{14}$ oleh karena itu perlu dilakukan penelitian untuk mengetahui kandungan metabolit sekunder pada daun sirsak yang digunakan dalam penelitian ini. Penelitian ini bertujuan untuk mengetahui aktivitas antibakteri ekstrak etanol daun sirsak terhadap S. mutans ATCC 35668 serta mengetahui profil metabolit sekunder dari ekstrak etanol daun sirsak (Annona muricata L.).

\section{METODE PENELITIAN}

Penelitian ini merupakan eksperimental murni. Penelitian telah mendapat persetujuan dari Tim Etik Penelitian Fakultas Kedokteran Gigi Universitas Gadjah Mada Yogyakarta (No.00247/KKEP/FKGUGM/EC/2015).

\section{a. Ekstraksi tanaman}

Daun sirsak yang digunakan berasal dari Balai Besar Penelitian dan Pengembangan Tanaman Obat dan Obat Tradisional Tawangmangu $\left(\mathrm{B}_{2} \mathrm{P}_{2}\right.$ TOOT), Litbangkes, Kemenkes RI dan telah dideterminasi (KM.03.02/NI.3/2004/2015). Daun sirsak dikeringkan dengan oven pada suhu $60{ }^{\circ} \mathrm{C}$ selama 2 jam. Simplisia daun sirsak yang telah kering dibuat serbuk halus dan disari dengan menggunakan pelarut etanol $70 \%$, diaduk dan didiamkan selama 24 jam, selanjutnya disaring. Filtrat diuapkan dengan vacuum rotary evaporator dalam waterbath dengan suhu $70^{\circ} \mathrm{C}$. Ekstrak kental yang dihasilkan dituang dalam cawan porselin, selanjutnya dipanaskan dengan waterbath suhu $60^{\circ} \mathrm{C}$ sambil terus diaduk dan menghasilkan ekstrak etanol daun sirsak (EEDS).

\section{b. Bakteri S.mutans ATCC 35668}

Bakteri S. mutans ATCC 35668 pada media Agar darah diambil beberapa koloni untuk disuspensikan dalam $5 \mathrm{ml} \mathrm{BHI}$ cair dan diinkubasi dalam inkubator suhu $37^{\circ} \mathrm{C}$ selama 24 jam. Larutan standar $0,5 \mathrm{Mc}$ Farland $\left(1,5 \times 10^{8} \mathrm{CFU} / \mathrm{ml}\right)$ digunakan sebagai standar turbiditas suspensi bakteri.

\section{c. Uji Kromatografi Lapis Tipis (KLT)}

Terpenoid: EEDS diekstraksi dengan 10 $\mathrm{ml}$ hexan selama 10 menit, disentrifugasi dan dievaporasi dengan gas nitrogen, kemudian ditambahkan $0,5 \mathrm{ml}$ hexan dan sampel dispotingpada plat silika gel $60 \mathrm{~F}_{254}$ sebanyak $10 \mu \mathrm{l}$. Langkah selanjutnya dimasukkan ke dalam chamber jenuh dengan fase gerak toluene-etil asetat (93:7) dan disemprot dengan pereaksi vanilin asam sulfat.

Steroid: Sampel EEDS ditambahkan etanol sebanyak $2 \mathrm{ml}$, kemudian divortex dan disentrifugasi. Langkah selanjutnya diteteskan pada plat silika gel $60 \mathrm{~F}_{254}$ sebanyak $20 \mu \mathrm{l}$ dan dimasukkan ke chamber jenuh dengan fase gerak Hexan:Etil Asetat (70:30) dan disemprot dengan pereaksi lieberman bucard.

Saponin: Sampel EEDS ditambahkan asam sulfat $2 \mathrm{~N}$ sebanyak $10 \mathrm{ml}$, kemudian dihidrolisis dengan pendingin balik dan didinginkan. Langkah 
berikutnya diekstraksi dengan $5 \mathrm{ml}$ kloroform. Fase kloroform diuapkan dengan gas nitrogen dan diteteskan pada plat silika gel $60 \mathrm{~F}_{254}$ sebanyak 10 $\mu \mathrm{l}$. Langkah selanjutnya dimasukkan ke chamber jenuh dengan fase gerak kloroform:metanol (95:5) dan disemprot dengan pereaksi anisaldehid asam sulfat.

Flavonoid: Sampel EEDS ditambahkan asam klorida $4 \mathrm{~N}$ sebanyak $10 \mathrm{ml}$, kemudian dihidrolisis dengan pendingin balik dan didinginkan. Langkah berikutnya diekstraksi dengan $5 \mathrm{ml}$ dietil eter dan diuapkan dengan gas nitrogen. Sampel dispoting pada plat selulosa dan dimasukkan ke chamber jenuh dengan fase gerak butanol-asam asetat-air (3:1:1) dan disemprot dengan pereaksi aluminium klorid.

Tanin: Sampel EEDS ditambahkan etanol $50 \%$ sebanyak $1 \mathrm{ml}$, kemudian divortex dan disentrifugasi. Fase cair dispoting sebanyak 10 $\mu \mathrm{l}$ pada plat silika gel, kemudian dimasukkan ke chamber jenuh dengan fase gerak etil asetatasam asetat-asam formiat-air (100-11-11-27) dan disemprot dengan pereaksi ferri klorid.

Alkaloid: Sampel EEDS ditambahkan amoniak $10 \%$ sebanyak $2 \mathrm{ml}$ dan $5 \mathrm{ml}$ kloroform, kemudian divortex dan disentrifugasi. Fase kloroform diuapkan dengan gas nitrogen dan dilarutkan dalam $200 \mu \mathrm{l} \mathrm{kloroform}$. Sampel dispoting sebanyak $20 \mu$ pada plat silika gel $F_{254}$, selanjutnya dimasukkan ke chamber jenuh dengan fase gerak metanol:amoniak $(100: 1,5)$ dan disemprot dengan pereaksi dragendorff.

\section{d. Uji Antibakteri}

Pengujian dilakukan dengan metode dilusi cair menggunakan 5 seri kadar uji. EEDS dilarutkan dalam DMSO 5\% untuk memperoleh konsentrasi sebesar 300; 250; 200; 150; 100 mg/ml. Kelima tabung tersebut kemudian ditambahkan $0,5 \mathrm{ml}$ suspensi bakteri $\left(1,5 \times 10^{7} \mathrm{CFU} / \mathrm{ml}\right)$ dalam media $\mathrm{BHI}$, sehingga konsentrasi akhir ekstrak dengan larutan suspensi bakteri dalam media BHI adalah 150; 125; $100 ; 75 ; 50 \mathrm{mg} / \mathrm{ml}$. Obat kumur Chlorhexidine 0,2\% digunakan sebagai kontrol positif dan DMSO $5 \%$ digunakan sebagai kontrol negatif. Ketujuh tabung tersebut selanjutnya divortex hingga suspensinya homogen dan diinkubasi selama 24 jam pada suhu $37^{\circ} \mathrm{C}$. Konsentrasi terkecil bahan uji pada tabung yang menunjukkan tidak adanya kekeruhan disebut sebagai Konsentrasi Hambat Minimal (KHM), selanjutnya disubkultur pada media Mueller Hinton Agar (MHA), diinkubasi pada suhu $37^{\circ} \mathrm{C}$ selama $2 \times 24$ jam. Streptococcus mutans ATCC 35668 yang tumbuh pada media MHA dihitung dan jumlah koloni bakteri dinyatakan dalam satuan $\mathrm{CFU} / \mathrm{ml}$. Setiap kelompok perlakuan dilakukan pengulangan sebanyak 5 kali.

\section{HASIL PENELITIAN}

Hasil uji fitokimia EEDS dengan metode Kromatografi Lapis Tipis (KLT) menunjukkan adanya kandungan senyawa-senyawa metabolit sekunder berupa saponin, terpenoid, steroid, flavonoid, tanin dan alkaloid. Hasil pengujian ekstrak etanol daun sirsak terhadap pertumbuhan S. mutans ATCC 35668 menunjukkan bahwa ekstrak tersebut mempunyai kemampuan untuk menurunkan jumlah koloni S. mutans ATCC 35668. Hasil menunjukkan semakin besar konsentrasi ekstrak maka semakin menghambat pertumbuhan S. mutans ATCC 35668. Konsentrasi $125 \mathrm{mg} / \mathrm{ml}$ merupakan Konsentrasi Hambat Minimal (KHM) dengan konsentrasi terendah yang kelarutannya terlihat jernih dan konsentrasi $150 \mathrm{mg} / \mathrm{ml}$ merupakan Kadar Bunuh Minimum (KBM) dengan konsentrasi terendah yang tidak menunjukkan adanya pertumbuhan S. mutans ATCC 35668 (Tabel 1 dan Gambar 1).

Hasil uji normalitas menggunakan ShapiroWilk menunjukkan $\mathrm{p}>0,05$ dan uji homogenitas dengan nilai $p<0,05$, hal ini menunjukkan bahwa data terdistribusi normal dan mempunyai varian yang berbeda sehingga dapat dilakukan uji parametrik menggunakan Anava satu jalur dengan post hoc Dunnett T3. ${ }^{15}$

Hasil uji Anava menunjukkan signifikansi sebesar 0,000 $(p<0,05)$, hal ini menunjukkan ekstrak etanol daun sirsak berpengaruh terhadap pertumbuhan koloni S. mutans ATCC 35668. Uji post hoc Dunnett T3 dilakukan pada tahap selanjutnya untuk mengetahui signifikansi perbedaan jumlah koloni antar kelompok perlakuan. 
Tabel 1. Rerata dan standar deviasi pertumbuhan S. mutans ATCC 35668 (CFU/ml) dalam berbagai konsentrasi ekstrak etanol daun sirsak (Annona muricata L.)

\begin{tabular}{cc}
\hline Kelompok perlakuan & Rerata \pm SD \\
\hline $50 \mathrm{mg} / \mathrm{ml}$ & $2,75 \times 10^{8} \pm 2,42 \times 10^{\prime}$ \\
$75 \mathrm{mg} / \mathrm{ml}$ & $2,10 \times 10^{8} \pm 1,08 \times 10^{7}$ \\
$100 \mathrm{mg} / \mathrm{ml}$ & $2,38 \times 10^{7} \pm 5,79 \times 10^{5}$ \\
$125 \mathrm{mg} / \mathrm{ml}$ & $9,70 \times 10^{6} \pm 7,60 \times 10^{5}$ \\
$150 \mathrm{mg} / \mathrm{ml}$ & $0,00 \pm 0,00$ \\
Kontrol negatif & $5,32 \times 10^{12} \pm 3,51 \times 10^{11}$ \\
Kontrol positif & $0,00 \pm 0,00$ \\
\hline
\end{tabular}

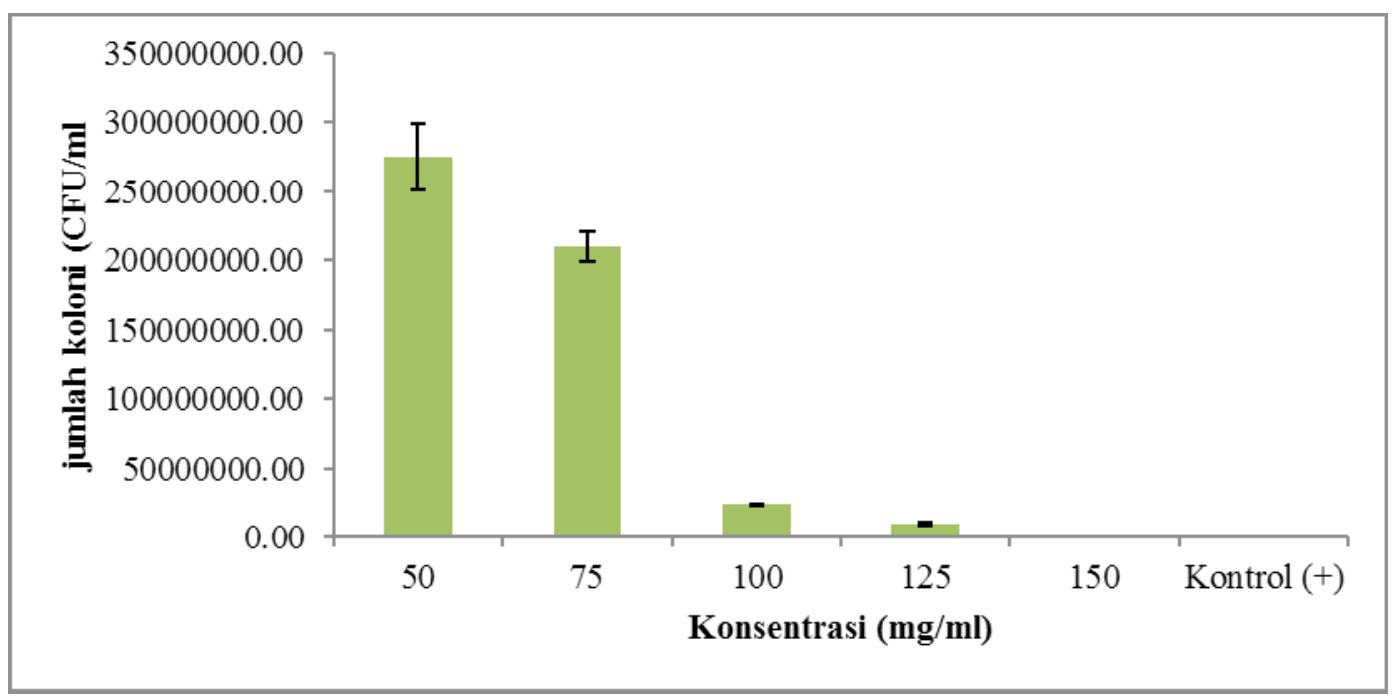

Gambar 1. Rerata dan standar deviasi pertumbuhan koloni S. mutans ATCC 35668 (CFU/ml) dalam berbagai konsentrasi ekstrak etanol daun sirsak

Hasil uji post hoc Dunnett T3 menunjukkan bahwa ekstrak etanol daun sirsak konsentrasi $50 \mathrm{mg} / \mathrm{ml}$ memiliki perbedaan jumlah koloni yang signifikan dengan konsentrasi $75 \mathrm{mg} / \mathrm{ml} ; 100 \mathrm{mg} / \mathrm{ml}$; $125 \mathrm{mg} / \mathrm{ml} ; 150 \mathrm{mg} / \mathrm{ml}$; kontrol negatif dan kontrol positif. Hal ini menunjukkan bahwa konsentrasi 50 $\mathrm{mg} / \mathrm{ml}$ sudah menurunkan jumlah koloni secara signifikan dibandingkan dengan kontrol negatif namun tidak signifikan menurunkan jumlah koloni bila dibandingkan dengan konsentrasi ekstrak etanol yang lebih tinggi. Konsentrasi $125 \mathrm{mg} /$ $\mathrm{ml}$ memiliki perbedaan yang signifikan dengan $150 \mathrm{mg} / \mathrm{ml}$; kontrol negatif dan kontrol positif. Hal ini menunjukkan bahwa konsentrasi $125 \mathrm{mg} / \mathrm{ml}$ tidak signifikan menurunkan jumlah koloni bila dibandingkan dengan konsentrasi ekstrak etanol $150 \mathrm{mg} / \mathrm{ml}$. Pada konsentrasi $150 \mathrm{mg} / \mathrm{ml}$ tidak menunjukkan perbedaan secara bermakna dengan kelompok kontrol positif. Hal tersebut menunjukkan bahwa konsentrasi $150 \mathrm{mg} / \mathrm{ml}$ merupakan konsentrasi yang mempunyai efektifitas yang sama dengan kontrol positif dalam menghambat pertumbuhan S. mutans ATCC 35668. Hasil penelitian ini menunjukkan bahwa semakin besar konsentrasi ekstrak etanol daun sirsak maka jumlah koloni $S$. mutans ATCC 35668 yang dapat dihambat pertumbuhannya juga semakin besar, hal ini dapat terlihat dari jumlah koloni (CFU/ml) yang semakin sedikit seiring dengan meningkatnya konsentrasi ekstrak etanol daun sirsak.

\section{PEMBAHASAN}

Skrining fitokimia dilakukan untuk memberikan gambaran tentang golongan senyawa yang terkandung dalam ekstrak. Hasil pemeriksaan skrining 
fitokimia ekstrak etanol daun sirsak (Annona muricata L.) menunjukkan adanya kandungan senyawa-senyawa metabolit sekunder berupa: saponin, terpenoid, steroid, flavonoid, tanin dan alkaloid.

Hasil pengujian ekstrak etanol daun sirsak menunjukkan bahwa ekstrak tersebut mempunyai kemampuan dalam menghambat pertumbuhan S. mutans ATCC 35668. Adanya kandungan tersebut memungkinkan ekstrak etanol daun sirsak mempunyai efek antibakteri yang bersifat menghambat pertumbuhan bakteri S. mutans ATCC 35668. Aktivitas antibakteri dipengaruhi beberapa faktor yaitu konsentrasi ekstrak, kandungan senyawa antibakteri, daya difusi ekstrak dan jenis bakteri yang dihambat. ${ }^{16}$ Saponin merupakan senyawa yang dikandung dalam ekstrak etanol daun sirsak, bersifat antibakteri dengan bekerja efektif pada bakteri Gram positif. ${ }^{17,18}$ Mekanisme kerja antibakteri dari saponin dengan cara meningkatkan permeabilitas membran sel sehingga membran menjadi tidak stabil dan mengakibatkan hemolisis sel. ${ }^{19}$

Senyawa flavonoid bersifat antibakteri melalui 3 mekanisme, yaitu: menghambat sintesis asam nukleat, menghambat fungsi membran sel dan menghambat metabolisme energi. Mekanisme kerja flavonoid dalam menghambat sintesis asam nukleat dilakukan melalui cincin B pada flavonoid yang mempunyai peranan penting dalam proses interkalasi atau ikatan hidrogen dengan menumpuk basa asam nukleat yang menghambat sintesis DNA dan RNA. ${ }^{20}$ Flavonoid menghambat fungsi membran sel bakteri melalui ikatan komplek dengan protein ekstraseluler yang bersifat larut sehingga dapat mengganggu integritas membran sel bakteri. ${ }^{13}$ Adanya gangguan dalam permeabilitas membran sel ini akan mempengaruhi gradien elektrokimia proton yang melewati membran. Gradien elektrokimia proton melintasi membran sangat penting bagi bakteri dalam mensintesis ATP, transport membran dan pergerakan bakteri, sehingga dengan adanya senyawa flavonoid akan menyebabkan terganggunya proton motive force yang berakibat terganggunya sintesis ATP, transport membran dan pergerakan bakteri. Selain itu penghambatan metabolisme energi bakteri oleh flavonoid dilakukan dengan cara menghambat proses respirasi bakteri sehingga adanya energi yang dihambat akan berpengaruh terhadap aktivitas penyerapan metabolit dan biosintesis makromolekul bakteri. ${ }^{20}$

Menurut Brooks ${ }^{16}$ struktur dinding sel bakteri juga menentukan penetrasi, ikatan dan aktivitas suatu senyawa antibakteri. Streptococcus mutans termasuk bakteri Gram positif dengan dinding sel yang tersusun oleh $40 \%-80 \%$ peptidoglikan/murein yang bisa mencapai hingga 40 lapisan. Pada bakteri Gram positif terdapat asam teikoid yang dihubungkan dengan peptidoglikan melalui ikatan kovalen. Asam teikoid ini bersifat hidrofilik (larut dalam air) dan berfungsi sebagai media transport ion bermuatan positif untuk keluar masuk ke dinding sel. ${ }^{21}$ Sifat larut air inilah yang menyebabkan dinding sel bakteri Gram positif bersifat lebih polar sehingga senyawa flavonoid akan lebih mudah menembus dinding sel $S$. mutans.

Kandungan senyawa tanin pada ekstrak etanol daun sirsak mempunyai aksi antibakteri yang berhubungan dengan kemampuannya untuk menonaktifkan adhesin bakteri, menghambat kerja enzim, menghambat transport protein pada selubung sel..$^{13}$ Menurut Akiyama ${ }^{22}$ dan Chung ${ }^{7}$ mekanisme kerja tanin sebagai bahan antibakteri antara lain melalui perusakan membran sel bakteri karena toksisitas tanin dan pembentukan ikatan komplek ion logam dari tanin yang berperan dalam toksisitas tanin. Bakteri yang tumbuh dalam kondisi aerob memerlukan zat besi untuk berbagai fungsi, termasuk reduksi dari prekursor ribonukleotida DNA. Adanya ikatan antara tanin dan besi akan menyebabkan terganggunya berbagai fungsi bakteri. Samaranayake ${ }^{1}$ menyatakan bahwa $S$. mutans merupakan bakteri fakultatif anaerob sehingga masih dapat hidup dalam kondisi aerob, apabila hidup dalam kondisi aerob maka bakteri akan terganggu dengan adanya senyawa tanin sebagaimana penelitian dilakukan dalam kondisi aerob. Penelitian $\mathrm{Xie}^{23}$ menunjukkan bahwa tanin mempunyai efek menghambat pertumbuhan $S$. mutans.

Kandungan alkaloid dalam ekstrak etanol daun sirsak mempunyai kemampuan antibakteri karena memiliki gugus aromatik kuartener yang mampu 
berinterkalasi dengan DNA, ${ }^{13}$ selain itu alkaloid juga mampu mengganggu integritas komponen penyusun peptidoglikan pada sel bakteri. Peptidoglikan merupakan komponen penyusun dinding sel bakteri sehingga adanya gangguan tersebut akan menyebabkan lapisan dinding sel tidak terbentuk secara utuh dan menyebabkan kematian sel. ${ }^{20}$ Susunan dinding bakteri $S$. mutans yang tersusun oleh lapisan peptidoglikan Trivedi ${ }^{21}$ akan terganggu dengan adanya alkaloid yang terkandung dalam ekstrak etanol daun sirsak sehingga berakibat terganggunya integritas dinding sel S. mutans.

Terpenoid merupakan salah satu senyawa yang dikandung oleh ekstrak etanol daun sirsak. Terpenoid mempunyai mekanisme antibakteri dengan cara pengrusakan membran sel bakteri. ${ }^{13}$ Kerusakan membran sel dapat terjadi ketika senyawa aktif antibakteri bereaksi dengan sisi aktif dari membran atau dengan melarutkan konstituen lipid dan meningkatkan permeabilitasnya. Membran sel bakteri terdiri dari fosfolipid dan molekul protein. Adanya peningkatan permeabilitas maka senyawa antibakteri dapat masuk ke dalam sel dan dapat melisis membran sel atau mengkoagulasi sitoplasma dari sel bakteri tersebut. ${ }^{24}$ Ekstrak etanol daun sirsak juga mengandung steroid. Pada penelitian dengan metode difusi yang dilakukan oleh Taleb-Contini ${ }^{25}$ menunjukkan bahwa steroid mempunyai kemampuan dalam menghambat pertumbuhan S. mutans.

Keseluruhan data menunjukkan bahwa kandungan aktif dalam ekstrak etanol daun sirsak mempunyai kemampuan dalam menghambat pertumbuhan S. mutans. Semakin tinggi konsentrasi ekstrak etanol daun sirsak maka kandungan senyawa aktif yang bersifat antibakteri semakin tinggi sehingga kemampuan dalam menghambat pertumbuhan S. mutans juga semakin besar. Hal ini sejalan dengan Brooks ${ }^{16}$ bahwa kemampuan suatu bahan dalam menghambat pertumbuhan bakteri dipengaruhi oleh besarnya konsentrasi antibakteri.

\section{KESIMPULAN}

Berdasarkan penelitian yang telah dilakukan dapat disimpulkan bahwa ekstrak etanol daun sirsak (Annona muricata L.) memiliki aktivitas antibakteri terhadap S. mutans ATCC 35668 dengan KHM pada konsentrasi $125 \mathrm{mg} / \mathrm{ml}$. Ekstrak etanol daun sirsak mengandung senyawa metabolit sekunder berupa saponin, terpenoid, steroid, flavonoid, tanin dan alkaloid.

\section{DAFTAR PUSTAKA}

1. Samaranayake L. Essential microbiology for dentistry $4^{\text {th }}$ ed. Churchil Livingstone Elsevier; 2012. $279-281$.

2. Metwalli $\mathrm{KH}$, Khan SA, Krom BP, Jabra-Rizk MA. Streptococcus mutans, candida albicans, and the human mouth: a sticky situation. PLOS Pathogens. 2013; 9(10): 1 - 5.

3. Brighenti FL, Luppens SBI, Delbem ACB, Deng DM, Hoogenkamp MA, Gaetti-Jardim JrE, Dekker HL, Crielaard W, Cate JM. Effect of psidium cattleianum leaf extract on streptococcus mutans viability protein expression and acid production. Caries Res. 2008; 42: 148 - 154.

4. Banas JA. Virulence properties of streptococcus mutans. Front Biosci-Landmrk. 2004; 9: 1267 - 1277.

5. Anusavice KJ. Present and future approaches for the control of caries. J Dent Educ. 2005; 69(5): $538-554$.

6. Marsh PD, Nyvad B. The oral microflora and biofilm on teeth in Fejerskov $\mathrm{O}$ and Kidd $\mathrm{E}$ (ed.): Dental caries the diseases and its clinical Management, $2^{\text {nd }}$ ed. Blackwell Munksgaard. UK; 2008. $164-185$.

7. Chung JY, Choo JH, Lee MH, Hwang JK. Anticariogenic activity of macelignan isolated from myristica fragans (nutmeg) against streptococcus mutans. Phytomedicine. 2006; 13(4): $261-266$.

8. Dhinahar S, Lakshmi T. Role of botanicals as antimicrobial agents in management of dental infections-a review. Int J Pharm Biol Sci. 2011; 2(4): $690-704$.

9. Tambunan S. Ensiklopedi tanaman obat tradisional. Materi Medika. Jakarta; 2011. 47 -68 . 
10. Foong CP, Hamid RA. Evaluation of antiinflammatory activities of ethanolic extracts of annona muricata leaves. Rev Bras Farmacogn Braz J Pharmacogn. 2012; 22(6): $1301-1307$.

11. Solomon-Wisdom GO, Ugoh SC, Mohammed $B$. Phytochemical screening and antimicrobial activities of annona muricata (L) leaf extract. Am J Biol Chem and Pharm Sci. 2014; 2(1): $1-7$.

12. Bhardwaj A, Bhardwaj SV. Role of medicinal herbs in prevention and treatment of dental diseases. Annals Ayurvedic Med. 2012; 1(3): $95-101$.

13. Cowan MM. Plant products as antimicrobial agents. Clin Micobiol Rev. 1999; 12(4): 564 582.

14. Kardono LBS. Kajian kandungan kimia mahkota dewa (phaleria marcocarpa).Pusat Penelitian dan Pengembangan Farmasi dan Obat Tradisional Badan Penelitian dan Pengembangan Kesehatan; 2003. 56.

15. Dahlan MS. Statistik untuk kedokteran dan kesehatan: deskriptif, bivariate, dan multivariat, dilengkapi dengan menggunakan SPPS edisi 6. Epidemiologi Indonesia. Jakarta; 2014. 91 117.

16. Brooks GF, Carol KC, Butel JS, Morse SA, Mietzner TA. Jawetz, melnick \& adelberg medical microbiology $25^{\text {th }}$ edition. The Mc Graw-Hill Companies. US; 2010. 56 - 62, 339 -370 .

17. Soetan KO, Oyekunle MA, Aiyelaagbe OO, Fafunso MA. Evaluation of the antimicrobial activity of saponins extract of sorghum bicolor I. moench. African J of Biotechnology. 2006; 5(23): $2405-2407$.
18. Hassan SM. Antimicrobial activities of saponinrich guar meal extract poultry science. Disertasi. A\&M University. Texas; 2008. 33 34.

19. Dewi ZY, Nur A, Hertriani T. Efek antibakteri dan penghambatan biofilm ekstrak sereh (cymbopogon nardus I.) terhadap bakteri streptococcus mutans. Majalah Kedokteran Gigi Indonesia. 2015; 1(2): 136 - 141.

20. Cushnie TPT, Lamb AJ. Antimicrobial activity of flavonoids. Int J Antimicrob Agents. 2005; 26: $343-356$.

21. Trivedi PC, Pandy S, Bhadauri S, Text book of microbiology $1^{\text {st }}$ ed. Aavishakar Publishers. India; 2010. 82 - 83.

22. Akiyama H, Fuji K, Yamasaki O, Oono $\mathrm{T}$, Iwatsuki T. Antibacterial action of several tannins against staphylococcus aureus. J Antimicrob Chemother. 2001; 48: 487 - 491.

23. Xie Q, Li J, Zhou X. Anticaries effect of compounds extracted from galla chinensis in a multispecies biofilm model. Oral Microbio Immunol. 2008; 23: 459 - 465.

24. Mayanti T, Julaeha E, Putri Y. Isolasi dan karakterisasi senyawa antibakteri dari fraksi etil asetat kulit batang lansium domesticum corr. cv kokossan. Universitas Padjajaran. Fakultas MIPA. Bandung; 2011. 10 - 11.

25. Taleb-Contini SH, Salvador MJ, Watanabe E, Ito IY, Oliveira DCR. Antimicrobial activity of flavonoids and steroids isolated from two chromolaena species. Braz J Pharm Sci. 2003; 39(4): 403 - 408. 